\title{
(NIE)SKUTECZNOŚĆ INSTYTUCJONALNEGO WSPARCIA UDZIELANEGO OSOBOM WYKOLEJAJĄCYM SIĘ W TRAJEKTORII ICH PRZESTĘPCZEJ KARIERY
}

\begin{abstract}
Noszczyk-Bernasiewicz Monika, (Nie)skuteczność instytucjonalnego wsparcia udzielanego osobom wykolejajacym się w trajektorii ich przestępczej kariery [(In)Effectiveness of Institutional Support Provided to Children and Youth Displaying Anti-Social Behaviour Over the Life Course]. Studia Edukacyjne nr 51, 2018, Poznań 2018, pp. 83-97. Adam Mickiewicz University Press. ISSN 1233-6688. DOI: 10.14746/se.2018.51.5
\end{abstract}

The article contains an in-depth qualitative analysis of 60 biographies of juvenile offenders in terms of the institutional (in)effectiveness of counteracting crime in the period before being placed in a closed facility. The analysis of the data shows that placement in a correctional facility is preceded by the application of many educational measures from supervision order to the decision to place a minor in an educational facility. Based on the collected data, it is possible to find a bad way of exercising parental care over the delinquents, and especially the ineffectiveness of the reactions undertaken by state institutions - remedial actions - including the family court.

Key words: juvenile delinquency, anti-social behavior, institutional care, social reaction

\section{Wstęp}

Zagrożenie dzieci i młodzieży różnymi formami niedostosowania społecznego, w tym przestępczością jest poważnym problemem społecznym. Stanowi też przedmiot zainteresowania licznego grona specjalistów (teoretyków, praktyków), ale również całego społeczeństwa, które je dostrzega, ocenia i domaga się ze strony państwa zdecydowanych w tym zakresie działań prewencyjnych oraz interwencyjnych. Wnioski płynące z analiz statystyki przestępczości wzmacniają potrzebę zajęcia się tą problematyką ${ }^{1}$. To wszyst-

${ }^{1}$ Zob. M. Noszczyk-Bernasiewicz, Demoralizacja i czyny karalne wśród nieletnich - dynamika i rozmiary, Resocjalizacja Polska, 2016, 11. 
ko skłania do zastanowienia się nad działaniami mającymi na celu zapobieganie i redukowanie wielu niepokojących zachowań wśród dzieci i młodzieży. Przestępczość nieletnich - według Anny Nowak - jawi się powszechnie jako ważny problem społeczny, wymagający wyjaśnienia i opisu, a przede wszystkim prowadzenia $\mathrm{w}$ tej dziedzinie interdyscyplinarnych badań, których zasadniczym celem jest poszukiwanie skutecznych działań w zakresie jej przeciwdziałania ${ }^{2}$. Toteż, profilaktyka $w$ rozumieniu zapobiegania wykolejaniu się społecznemu, zwłaszcza zaś przestępczości, oznacza system określonych środków państwowych i społecznych, których celem jest: usuwanie przyczyn powstawania tego zjawiska i sprzyjających mu okoliczności, ograniczanie możliwości występowania wszelkiego rodzaju czynników kryminogennych, a także reagowanie $\mathrm{w}$ odpowiednim czasie przez organy państwowe i społeczne na tego typu (antyspołeczne) zachowanie jednostki ${ }^{3}$. Stąd, bardzo ważne wydaje się poznanie działań pre- i postdeliktualnych (przed i poprzestępczych), a tym samym systemu radzenia sobie z problemami dotykającymi dzieci i młodzież, w tym z przestępczością.

\section{Metodologia}

Prezentowany materiał badawczy pochodzi z badań własnych, realizowanych w latach 2010-2012. Obecnie postawiono sobie jednak zupełnie nowy cel. W przyjętym postępowaniu badawczym posłużono się metodą indywidualnych przypadków, w którym jednostką analizy uczyniono przebieg życia osób niedostosowanych społecznie oraz reakcje podejmowane wobec naruszania przez nie norm prawnych i obyczajowych ${ }^{4}$. Dariusz Kubinowski zauważa, że:

komponentami studium przypadku/ przypadków są: istota przypadku, jego tło historyczne, otoczenie fizyczne, konteksty ekonomiczne, polityczne, prawne, dodatkowe przypadki służące do jego lepszego rozpoznania, respondenci, dzięki któremu przypadek został poznany ${ }^{5}$.

W postępowaniu badawczym zastosowano technikę badawczą analizy dokumentów w postaci akt sądowych i zakładowych pod kątem podejmo-

${ }^{2}$ A. Nowak, Młodzież o przyczynach, przejawach, skutkach i profilaktyce przestępczości nieletnich, [w:] Bezpieczeństwo dzieci i młodzieży i jego zagrożenia, red. K. Czarnecki, W. Kojs, M. Rozmus, Mysłowice 2001, s. 97.

${ }^{3}$ M. Kalinowski, Z praktyki i teorii pracy profilaktycznej w środowisku wychowawczym, Warszawa 1986, s. 9.

${ }^{4}$ Zob. A. Gromkowska-Melosik, Elitarne szkolnictwo średnie. Między reprodukcja społeczno-kulturowa a ruchliwością konkurencyjna, Poznań 2015, s. 279.

${ }^{5}$ D. Kubinowski, Jakościowe badania pedagogiczne. Filozofia-metodyka-ewaluacja, Lublin 2010, s. 172. 
wanych działań zaradczych (reakcji) ze strony różnych podmiotów udzielających nieletnim oraz ich rodzicom pomocy i wsparcia. Terenem badań objęto cztery zakłady poprawcze i schroniska dla nieletnich (dalej ZP i SdN), to jest z Koronowa, Pszczyny, Raciborza i Zawiercia. W ZP i SdN w Raciborzu oraz Pszczynie przebywają nieletni chłopcy, natomiast w Koronowie i w Zawierciu - nieletnie dziewczęta. Analizie poddano 60 teczek nieletnich, w tym 26 chłopców i 34 dziewcząt. Literami Z, K, P, R oznaczono badanych nieletnich w zależności od miejsca ich pobytu, na przykład Z jak Zawiercie.

Tabela 1

Wiek badanych wychowanków z ZP i SdN w momencie realizacji badań

$(\mathrm{N}=60 ; 100 \%)$

\begin{tabular}{|c|c|c|c|}
\hline \multirow{2}{*}{ Wiek } & \multicolumn{2}{|c|}{ Płeć badanych } & \multirow{2}{*}{$\begin{array}{c}\text { Razem } \\
\text { N }=60\end{array}$} \\
\cline { 2 - 3 } & dziewczęta $(\mathrm{n}=34)$ & chłopcy $(\mathrm{n}=26)$ & 1 \\
\hline 14 lat & - & 1 & $\mathbf{8}$ \\
\hline 15 lat & 2 & 6 & $\mathbf{1 2}$ \\
\hline 16 lat & 8 & 4 & $\mathbf{1 5}$ \\
\hline 17 lat & 9 & 6 & $\mathbf{1 0}$ \\
\hline 18 lat & 3 & 7 & $\mathbf{9}$ \\
\hline 19 lat & 8 & 1 & $\mathbf{3}$ \\
\hline 20 lat & 2 & 1 & $\mathbf{2}$ \\
\hline 21 lat & 2 & - & \\
\hline
\end{tabular}

Źródło: badania własne.

Badane osoby liczyły od 14. do 21. lat, w tym najliczniej reprezentowane w populacji badawczej były kolejno osoby w wieku 17, 16 i 18 lat, pochodzące najczęściej z dużych miast, powyżej 200 tys. mieszkańców (22 osoby) i średnich miast, to jest pomiędzy 50 a 200 tys. mieszkańców (20 osób). Tylko 2. nieletnich było mieszkańcami wsi.

\section{Analiza uzyskanych wyników badań}

O profilaktyce $\mathrm{w}$ wychowaniu mówi się $\mathrm{w}$ dwóch znaczeniach - jako o profilaktyce uprzedzającej i profilaktyce objawowej. Profilaktyka uprzedzająca polega na zapobieganiu niepożądanym zjawiskom, które jeszcze nie wystąpiły, ale których - na podstawie posiadanej na przykład przez nauczyciela, wychowawcę, pedagoga, czy pracownika socjalnego wiedzy (np. otrzymywanych sygnałów) - można się spodziewać. Ten rodzaj profilaktyki uważany jest przez specjalistów za najbardziej skuteczny, z racji podejmowania działań poprzedzających pojawienie się niepożądanych zachowań. Oznacza 
to, że im wcześniej zauważymy niekorzystne tendencje w zachowaniu dziecka (ucznia, wychowanka) czy też niekorzystnie oddziałujące na niego czynniki tkwiące $\mathrm{w}$ jego środowisku (rodzinnym, szkolnym, czy rówieśniczym) i na nie odpowiednio zareagujemy, tym większe są szanse ograniczenia czy też wyeliminowania działania wobec niego czynników ryzyka. Profilaktyka objawowa to działalność wychowawcza, podejmowana w sytuacji, kiedy pojawią się pierwsze symptomy niepokojących zachowań, zjawisk, czy też zdarzeń. Chodzi w niej o wczesne rozpoznawanie objawów niepożądanych zachowań, jak również natychmiastowe podejmowanie działań zapobiegawczych $^{6}$. Dlatego najpierw w prowadzonych analizach zwrócono uwagę na to, $\mathrm{w}$ jakim wieku byli badani wychowankowie $\mathrm{ZP}$ i SdN, gdy zostały podjęte wobec nich pierwsze reakcje.

Tabela 2

Wiek badanych w momencie podjęcia pierwszych wobec nich działań (reakcji)

$(\mathrm{N}=60 ; 100 \%)$

\begin{tabular}{|c|c|c|c|}
\hline \multirow{2}{*}{ Wiek } & \multicolumn{2}{|c|}{ Płeć badanych } & \multirow{2}{*}{ Razem } \\
\cline { 2 - 3 } & dziewczęta $(\mathrm{n}=34)$ & chłopcy $(\mathrm{n}=26)$ & $\mathbf{3}$ \\
\hline 0 do 1. roku urodzenia & 1 & 2 & $\mathbf{1}$ \\
\hline 1 rok & 1 & - & $\mathbf{1}$ \\
\hline 2 lata & 1 & - & 1 \\
\hline 4 lata & 1 & - & $\mathbf{5}$ \\
\hline 5 lat & 3 & 2 & $\mathbf{1}$ \\
\hline 6 lat & 1 & - & $\mathbf{4}$ \\
\hline 7 lat & 4 & - & $\mathbf{4}$ \\
\hline 8 lat & 3 & 1 & 3 \\
\hline 9 lat & 1 & 2 & $\mathbf{6}$ \\
\hline 10 lat & 4 & 2 & $\mathbf{7}$ \\
\hline 11 lat & 2 & 5 & $\mathbf{4}$ \\
\hline 12 lat & 3 & 1 & $\mathbf{5}$ \\
\hline 13 lat & 1 & 4 & 6 \\
\hline 14 lat & 4 & 2 & $\mathbf{3}$ \\
\hline 15 lat & 2 & 1 & $\mathbf{2}$ \\
\hline 16 lat & 1 & 1 & $\mathbf{4}$ \\
\hline Brak danych & 1 & 3 & \\
\hline
\end{tabular}

Źródło: badania własne.

${ }^{6}$ K. Ostaszewski, Skuteczność profilaktyki używania substancji psychoaktywnych, Warszawa 2003, s. 20-21. 
Pogłębiona analiza zebranego materiału wykazała, że wiekiem w którym podejmowano najczęściej pierwsze działania (reakcje) był 11. rok życia, co odnotowano u 7. badanych wychowanków. Na drugiej pozycji znaleźli się 10. i 14-latkowie (po 6 badanych). Kolejny, najczęściej występujący wiek podjęcia pierwszych działań zaradczych przypadł na 5. rok życia (5 badanych). Zestawiając powyższe dane w cztery przedziały wiekowe 0-4 lata, 5-8 lat, 9-12 lat oraz 13-16 lat, okazuje się, że najczęściej do podjęcia pierwszych działań zaradczych dochodziło w grupie osób w wieku 9-12. rok życia (było tak w 20. przypadkach). Kolejną grupą były osoby pomiędzy 13. a 16. rokiem życia (16 osób). Przeprowadzona analiza pokazuje, że podjęcie pierwszej reakcji następowało zbyt późno (w wieku 9-12 lat albo jeszcze później), a czasem najbardziej istotnym dla rozwoju człowieka jest okres do 5. roku życia, ponieważ właśnie wówczas kształtują się najbardziej trwałe, podług teorii behawioralnej oraz psychodynamicznej, predyspozycje poznawczo-emocjonalne.

Można by wysunąć tezę, że reakcja następowała tak późno, ponieważ wcześniej nic niepokojącego nie działo się w rodzinach nieletnich. Teza taka nie znajduje jednak potwierdzenia w analizowanej populacji badawczej, którą cechuje raczej wychowywanie się od samego początku w rodzinie wieloproblemowej. Poniższy fragment dokumentacji nieletniego stanowi odzwierciedlenie tej prawidłowości:

Chłopiec do 9. roku życia pozostawał pod opieka rodziców biologicznych, którzy nie wywiązywali się ze swoich ról jako opiekunowie. Zaniedbywali potrzeby dzieci, nie zapewniali im właściwych warunków socjalno-bytowych. Rodzinę tę cechowat duży poziom patologii w postaci nadużywania alkoholu przez rodziców, konfliktów, przemocy w rodzinie oraz karalności sądowej ojca. Okres ten miat niewatpliwie istotny wpływ na ksztattowanie się osobowości chłopca. W związku z powyższym można mówić o deficytach w zakresie umiejętności kontroli własnej popędowości, internalizacji norm społecznych, adekwatnej oceny własnego postepowania, co ma wptyw na obecne zachowanie chłopca, w tym zachowanie o charakterze seksualnym. (...) chłopiec przebywa (...) w rodzinie zastepczej od 9. roku życia. Wcześniej był wychowywany w rodzinie, w której był alkohol, znęcanie się i zaniedbywanie dzieci. (...) Nieletni bardzo niechętnie wspomina i wraca do tamtego okresu swojego życia. Przyjmuje postawe odcięcia się od przeszłości. Od około 6 lat wychowuje się w rodzinie zastepczej, w której zostat umieszczony wraz z rodzeństwem. Do rodziców zastępczych z własnej woli zwraca się tata, mama (Nieletni 1R).

Następnie postanowiono dokonać wyszczególnienia „pierwszych” reakcji podjętych wobec badanych wychowanków. 
Rodzaje podjętych "pierwszych” działań wobec badanych

$(\mathrm{N}=60 ; 100 \%)$

\begin{tabular}{|c|c|c|c|}
\hline \multirow[b]{2}{*}{ Rodzaj działania } & \multicolumn{2}{|c|}{ Płeć badanych } & \multirow[b]{2}{*}{$\begin{array}{l}\text { Razem } \\
\mathrm{N}=60\end{array}$} \\
\hline & $\begin{array}{c}\text { dziewczęta } \\
(\mathrm{n}=34)\end{array}$ & $\begin{array}{l}\text { chłopcy } \\
(\mathrm{n}=26)\end{array}$ & \\
\hline $\begin{array}{l}\text { Umieszczenie w placówce opiekuńczo-wycho- } \\
\text { wawczej typu socjalizacyjnego i interwencyj- } \\
\text { nego }\end{array}$ & 4 & 8 & 12 \\
\hline Ustanowienie nadzoru kuratora & 10 & 1 & 11 \\
\hline $\begin{array}{l}\text { Ustanowienie nadzoru kuratora nad rodziną } \\
\text { w związku z ograniczeniem wykonywania } \\
\text { władzy rodzicielskiej }\end{array}$ & 6 & 3 & 9 \\
\hline Zastosowanie leczenia szpitalnego & 3 & 4 & 7 \\
\hline Umieszczenie w rodzinie zastępczej & 4 & 2 & 6 \\
\hline $\begin{array}{l}\text { Leczenie psychiatryczne ambulatoryjne i szpi- } \\
\text { talne }\end{array}$ & 4 & 2 & 6 \\
\hline $\begin{array}{l}\text { Skierowanie do poradni psychologiczno-peda- } \\
\text { gogicznej }\end{array}$ & 1 & 2 & 3 \\
\hline Umieszczenie w schronisku dla nieletnich & 1 & 1 & 2 \\
\hline $\begin{array}{l}\text { Udzielenie upomnienia ze strony sądu rodzin- } \\
\text { nego (środek wychowawczy) }\end{array}$ & 1 & - & 1 \\
\hline Uczęszczanie do świetlicy środowiskowej & 1 & - & 1 \\
\hline Pomoc ze strony MOPS-u & 1 & - & 1 \\
\hline $\begin{array}{l}\text { Przeprowadzenie testów na obecność narkoty- } \\
\text { ków }\end{array}$ & - & 1 & 1 \\
\hline
\end{tabular}

Źródło: badania własne.

Badania pokazały, że najczęściej podejmowanymi reakcjami wobec badanych było orzeczenie przez sąd rodzinny umieszczenia w placówce opiekuńczo-wychowawczej typu socjalizacyjnego (dom dziecka, dom małego dziecka) i typu interwencyjnego (pogotowie opiekuńcze) lub w rodzinie zastępczej (18 na 60 badanych), następnie nadzór kuratora - środek wychowawczy, który został orzeczony wobec 11. badanych. Ograniczenie władzy rodzicielskiej poprzez ustanowienie nad nią nadzoru ze strony kuratora sądowego miało miejsce w 9. przypadkach. Nieco mniejszą grupę (7 osób) stanowili nieletni, wobec których zastosowano leczenie szpitalne. Najczęstszą przyczyną podjęcia leczenia szpitalnego przez badanych wychowanków były: przebyte urazy wskutek wypadków komunikacyjnych, wrodzone wady (np. serca), nabyte we wczesnym dzieciństwie schorzenia (zakrzepica, problemy w tarczycą, zarażenie prątkiem gruźlicy itp.). Uzyskane wyniki wskazują na skrajną niewydolność 
środowiska rodzinnego, z którego prawie 1/3 badanych musiała chociaż raz w swoim życiu zostać zabrana celem zabezpieczenia dobra dziecka.

Tabela 4

Wiek wystąpienia pierwszych symptomów demoralizacji wśród badanych

$$
(\mathrm{N}=60 ; 100 \%)
$$

\begin{tabular}{|c|c|c|c|}
\hline \multirow{2}{*}{ Wiek } & \multicolumn{2}{|c|}{ Płeć badanych } & \multirow{2}{*}{ Razem } \\
\cline { 2 - 3 } & dziewczęta $(\mathrm{n}=34)$ & chłopcy $(\mathrm{n}=26)$ & $\mathbf{1 1}$ \\
\hline 7 lat & 5 & 6 & $\mathbf{7}$ \\
\hline 8 lat & 4 & 3 & $\mathbf{5}$ \\
\hline 9 lat & 4 & 1 & $\mathbf{4}$ \\
\hline 10 lat & 2 & 2 & $\mathbf{8}$ \\
\hline 11 lat & 7 & 1 & $\mathbf{6}$ \\
\hline 12 lat & 5 & 1 & $\mathbf{5}$ \\
\hline 13 lat & 4 & 1 & $\mathbf{4}$ \\
\hline 14 lat & 1 & 3 & $\mathbf{1}$ \\
\hline 15 lat & 1 & - & $\mathbf{1}$ \\
\hline 16 lat & - & 1 & $\mathbf{8}$ \\
\hline Brak danych & 1 & 7 & \\
\hline
\end{tabular}

Źródło: badania własne.

Badania wykazały, że 7. rok życia to najczęściej występujący wiek pojawienia się pierwszych symptomów demoralizacji wśród badanych. Taka in-

${ }^{7} \mathrm{Na}$ podstawie pogłębionej analizy danych z teczek osobopoznawczych przebadano strukturę rodziny pochodzenia badanych $w$ dwóch odstępach czasu, tj. tuż po ich urodzeniu oraz tzw. „aktualną", czyli tą sprzed umieszczenia w placówce resocjalizacyjnej (SdN lub ZP). Według uzyskanych wyników badań, na 60 badanych $54 \mathrm{w}$ pierwszych miesiącach, a niekiedy latach swojego życia wzrastało $\mathrm{w}$ rodzinach pełnych. Kolejne 5 osób pochodziło z rodzin niepełnych biologicznie, tylko 1 osoba od narodzin wzrastała w domu dziecka. Natomiast sytuacja dotycząca struktury rodziny pochodzenia przed umieszczeniem nieletnich $\mathrm{w}$ placówce resocjalizacyjnej diametralnie się zmieniła, bowiem dominującą grupę (26 osób) stanowili nieletni, którzy byli podopiecznymi placówek opiekuńczo-wychowawczych lub pozostawali pod opieką czasowego nieformalnego opiekuna zastępczego. Po 12 badanych wychowywało się $\mathrm{w}$ rodzinach zrekonstruowanych i niepełnych. Rodziny pełne nadal miało tylko 7 badanych wychowanków. Początkowa liczba 54 badanych wychowujących się w rodzinach pełnych z czasem spadła do 7 osób. 47 badanych wychowanków straciło w przebiegu swojego życia szansę na wychowywanie się w rodzinie pełnej. Ta analiza (w dwóch odstępach czasu) pokazała też jeszcze inną negatywną tendencję. Po urodzeniu odnotowano tylko 1 przypadek badanego, który od urodzenia przebywał w placówce opiekuńczo-wychowawczej, natomiast tuż przed umieszczeniem badanych w placówce resocjalizacyjnej (ZP lub SdN) w takiej sytuacji było aż 26 wychowanków. Zob. M. Noszczyk-Bernasiewicz, Płynna struktura rodziny pochodzenia w biografiach nieletnich przestępców, [w:] Sociální pedagogika v kontextu životních etap člověka, red. M. Bargel, E. Janigová, E. Jarosz, M. Jůzl, Brno 2013. 
formacja widniała w dokumentacji 11. badanych wychowanków, czego dowodem jest fragment historii nieletniego:

Analiza trudności wychowawczych i procesu wykolejenia: trudności wychowawcze z nieletnim sygnalizowane byty od poczatku jego nauki w szkole podstawowej, dotyczyly one niesubordynacji w czasie lekcji i zachowan zagrażających bezpieczeństwu innych dzieci, m.in.: popychanie kolegów na schodach, częste wdawanie się w konflikty. W kolejnych latach funkcjonowanie nieletniego w roli ucznia byto coraz gorsze. Chodzit po klasie w czasie zajeć uniemożliwiając ich prowadzenie, zaczepiat, straszyt, szantażowat innych uczniów, lekceważył obowiąki dydaktyczne, byt wulgarny $i$ arogancki w stosunku do przełożonych, wagarowat (Nieletni 15R).

Prowadzona na przestrzeni 15 lat (2000 - 2014) analiza danych statystycznych Ministerstwa Sprawiedliwości wykazała zwiększającą się liczbę nieletnich zdemoralizowanych i sprawców czynów karalnych w najniższych kategoriach wieku. Nieletnich do lat 9 (w kategorii tej znalazły się również młodsze dzieci, tj. do lat 5, 6, 7 i 8-letnie) na przestrzeni analizowanego okresu przybyło o 99 osób. W tym samym czasie odnotowano znaczny wzrost (aż o 467 osób - 16,7\%) tak zwanych młodszych nieletnich - to jest osób, które nie ukończyły 13. roku życia8.

Także pogłębiona analiza badań własnych wykazała podobną tendencję, ponieważ ponad 2/3 badanych (41 osób), u których stwierdzono pierwsze symptomy demoralizacji, nie miało ukończonego 13. roku życia. Znaczną część tej grupy (27 osób) stanowili wychowankowie, którzy pierwsze symptomy demoralizacji zaczęli ujawniać w okresie przypadającym na pierwsze lata szkoły podstawowej. Obniżenie wieku nieletnich jest wynikiem wielu czynników, w tym braku odpowiedniej opieki, zaniedbań wychowawczych ze strony rodziców, a przede wszystkim stanowi efekt braku podejmowania we właściwym czasie odpowiednich środków zaradczych (reakcji) wobec analizowanych tutaj zjawisk przez pracowników instytucji publicznych do tego powołanych.

Tabela 5 Rodzaje podejmowanych działań po wystąpieniu pierwszych symptomów demoralizacji $(\mathrm{N}=60 ; 100 \%)$

\begin{tabular}{|l|c|c|c|}
\hline \multirow{2}{*}{ Rodzaj działania } & \multicolumn{2}{|c|}{ Płeć badanych } & \multirow{2}{*}{$\begin{array}{c}\text { Razem } \\
\text { N =60 }\end{array}$} \\
\cline { 2 - 3 } & $\begin{array}{c}\text { dziewczęta } \\
(\mathrm{n}=34)\end{array}$ & $\begin{array}{c}\text { chłopcy } \\
(\mathrm{n}=26)\end{array}$ & $\mathbf{1 9}$ \\
\hline Ustanowienie nadzoru kuratora & 16 & 3 & $\mathbf{6}$ \\
\hline $\begin{array}{l}\text { Umieszczenie w młodzieżowym ośrodku } \\
\text { wychowawczym }\end{array}$ & 3 & 3 & \\
\hline
\end{tabular}

${ }^{8}$ Zob. Zob. M. Noszczyk-Bernasiewicz, Demoralizacja i czyny, s. 149. 


\begin{tabular}{|l|c|c|c|}
\hline $\begin{array}{l}\text { Skierowanie do poradni psychologiczno-pe- } \\
\text { dagogicznej }\end{array}$ & 3 & 2 & 5 \\
\hline Skierowanie do poradni zdrowia psychicznego & 2 & 3 & $\mathbf{5}$ \\
\hline Umieszczenie w izbie wytrzeźwień & 1 & 3 & $\mathbf{4}$ \\
\hline Umieszczenie w schronisku dla nieletnich & 2 & 2 & $\mathbf{4}$ \\
\hline $\begin{array}{l}\text { Umieszczenie w placówce opiekuńczo-wy- } \\
\text { chowawczej typu interwencyjnego }\end{array}$ & 1 & 2 & $\mathbf{3}$ \\
\hline Umieszczenie w szpitalu psychiatrycznym & 1 & 2 & $\mathbf{3}$ \\
\hline Konsultacja psychiatryczna & 1 & 2 & $\mathbf{2}$ \\
\hline Umieszczenie w izbie dziecka & 2 & - & $\mathbf{1}$ \\
\hline Umieszczenie w ośrodku leczenia uzależnień & - & 1 & $\mathbf{1}$ \\
\hline $\begin{array}{l}\text { Umieszczenie w ośrodku szkolno-wycho- } \\
\text { wawczym }\end{array}$ & 1 & - & $\mathbf{1}$ \\
\hline $\begin{array}{l}\text { Udzielenie upomnienia ze strony sądu rodzin- } \\
\text { nego (środek wychowawczy) }\end{array}$ & 1 & 1 & $\mathbf{1}$ \\
\hline Skierowanie do ochotniczego hufca pracy & - & - & 1 \\
\hline $\begin{array}{l}\text { Przeprowadzenie testów na obecność narko- } \\
\text { tyków }\end{array}$ & & & \\
\hline
\end{tabular}

Źródło: badania własne.

Jak wykazują prezentowane wyniki badań, wobec prawie $1 / 3$ badanych (19. osób) najczęściej podejmowanym działaniem (reakcją) w sytuacji ujawnianych przez nich pierwszych symptomów demoralizacji był nadzór kuratora. Na drugiej pozycji (pod względem częstotliwości stosowania) znalazł się inny środek wychowawczy $\mathrm{w}$ postaci umieszczenia $\mathrm{w}$ młodzieżowym ośrodku wychowawczym. Trzecie miejsce (po 5. badanych) zajęło udzielenie pomocy przez poradnię psychologiczno-pedagogiczną (PPP) oraz ze strony poradni zdrowia psychicznego (PZP). Po 4. nieletnich zostało umieszczonych w izbie wytrzeźwień lub w schronisku dla nieletnich. Poniższy fragment analizy trudności wychowawczych i długiego procesu wykolejenia się nieletniej pokazuje, że pierwszą podjętą wobec niej reakcją - pomimo wieloletniego ujawniania się symptomów demoralizacji - było umieszczenie jej w schronisku dla nieletnich:

(...) z dostępnych materiatów informacyjnych wynika, że pierwsze symptomy świadczace o zakłóceniu w prawidłowym funkcjonowaniu nieletniej pojawity się, kiedy była uczennica klasy VI SP. Wystapity w postaci zmniejszania sie motywacji szkolnej, gorszych ocen, nieprzygotowania do zajęć. Po rozpoczęciu nauki w gimnazjum nadal niesystematycznie przygotowywata się do lekcji, a ponadto samowolnie zaczęta opuszczać zajęcia. W pierwszym roku nauki opuściła bez 
usprawiedliwienia się 83 godziny, w drugim 151. Podczas wagarów przebywała $w$ domu. $Z$ wywiadu środowiskowego zawartego w aktach sprawy wynika, ze w ocenie rówieśników z miejsca zamieszkania nieletnia utrzymywała kontakty ze zdemoralizowanymi osobami, spędzata czas do późnych godzin nocnych poza domem, piła alkohol, wielokrotnie uczestniczyła w bójkach, utrzymywała kontakty seksualne z różnymi osobami. $Z$ wypowiedzi nieletniej, rodziców oraz opinii zawartych w aktach sprawy, w tym opinii ze szkoty wynika, że czas wolny spedzata najczęściej w otoczeniu młodzieży z tej samej miejscowości. Organizowali ogniska, dyskoteki. Rodzice zawsze wiedzieli, gdzie nieletnia przebywa i z kim, akceptowali środowisko koleżeńskie. Dwukrotnie zdarzyło się, że nie wróciła do domu na noc, przebywała wówczas na terenie wsi ze swoimi znajomymi. Z relacji nieletniej wynika, że podczas wspólnie organizowanych imprez zdarzato się, że pita alkohol w postaci piwa. Raz upita się. Od poczatku 2006 roku jej relacje $z$ dotychczasowym środowiskiem koleżeńskim uległy zerwaniu. Bezpośrednim powodem byt konflikt zakończony bójka z koleżanka, podczas której dwaj koledzy pobili nieletnia, co zgłosił policji jej ojciec. $W$ dniu (...) nieletnia dokonata czynu karalnego pozbawiając życia matoletnia, która wcześniej pobiła, która traktowała jako rywalkę, przeszkodę w utrzymaniu bliskich kontaktów uczuciowych z chłopcem (Nieletnia 27K).

Przytoczona historia jest niekwestionowanym dowodem, że istotnym elementem $\mathrm{w}$ zapobieganiu niedostosowaniu społecznemu wśród dzieci i młodzieży jest bezzwłoczne podejmowanie działań mających na celu kontrolowanie wszelkich zachowań bezprawnych, a tym samym ograniczanie możliwości ujawniania przez takie osoby skłonności do podejmowania działań, które kolidują z obowiązującymi normami prawnymi i obyczajowymi. Tymczasem, powyższy przykład jest dowodem na inercję systemu reagowania, którą odnotowuje również Grzegorz Harasimiak ${ }^{9}$ pisząc, że następuje swoiste zwlekanie z podjęciem interwencji, aż do momentu ujawnienia demoralizacji w najostrzejszej formie, to jest popełnienia czynu zabronionego.

Analiza danych pod kątem czasu jaki upłynął pomiędzy wystąpieniem $\mathrm{u}$ badanych pierwszych symptomów demoralizacji a podjętą wobec nich reakcją wykazała, że najczęściej były one podejmowane w trybie natychmiastowym, to jest $\mathrm{w}$ tym samym roku co zaistniałe zdarzenie lub 1 rok później. Pozytywny wydźwięk takiego wyniku przeprowadzonej analizy osłabiają kolejne pozycje $w$ tabeli, ponieważ wysoką - 3 pozycję - zajęła 4-letnia odległość czasowa, zaś 5, 6, czy nawet 7-letnie odstępy czasu pomiędzy wystąpieniem pierwszych symptomów demoralizacji a podjętą reakcją nie były przypadka-

${ }^{9}$ G. Harasimiak, Problem zachowań przestępczych dzieci i młodzieży, Opieka - Wychowanie Terapia, 2005, 3-4, s. 15. 
Tabela 6

Czas pomiędzy wystąpieniem pierwszych symptomów demoralizacji a podjętą reakcją

$(\mathrm{N}=60 ; 100 \%)$

\begin{tabular}{|l|c|c|c|c|}
\hline \multirow{2}{*}{ Lata } & \multicolumn{2}{|c|}{ Płeć badanych } & \multirow{2}{*}{$\begin{array}{c}\text { Razem } \\
\mathrm{N}=60\end{array}$} & $\begin{array}{c}\text { Ranga / po- } \\
\text { zycja }\end{array}$ \\
\cline { 2 - 5 } & $\begin{array}{c}\text { dziewczęta } \\
(\mathrm{n}=34)\end{array}$ & $\begin{array}{c}\text { chłopcy } \\
(\mathrm{n}=26)\end{array}$ & $\mathbf{9}$ & $\mathbf{1}$ \\
\hline Ten sam rok & 5 & 3 & $\mathbf{9}$ & $\mathbf{1}$ \\
\hline Powyżej 1. roku & 6 & - & $\mathbf{6}$ & $\mathbf{4}$ \\
\hline 2 lata & 6 & 1 & $\mathbf{5}$ & $\mathbf{5}$ \\
\hline 3 lata & 4 & 4 & $\mathbf{7}$ & $\mathbf{3}$ \\
\hline 4 lata & 3 & 1 & $\mathbf{5}$ & $\mathbf{5}$ \\
\hline 5 lat & 4 & 3 & $\mathbf{5}$ & $\mathbf{5}$ \\
\hline 6 lat & 2 & 2 & $\mathbf{4}$ & $\mathbf{6}$ \\
\hline 7 lat & 1 & - & $\mathbf{1}$ & $\mathbf{7}$ \\
\hline 8 lat & - & 1 & $\mathbf{1}$ & $\mathbf{7}$ \\
\hline 9 lat & 1 & 7 & $\mathbf{8}$ & $\mathbf{2}$ \\
\hline Brak danych & & & & \\
\hline
\end{tabular}

Źródło: badania własne.

mi incydentalnymi. Dane zawarte w dokumentach badanych nieletnich wykazały, że ta odległość czasowa wynosiła nawet 8 i 9 lat. Dane ilościowe odnoszące się do spóźnionych reakcji społecznych wobec ujawnionej demoralizacji potwierdzają następujące fragmenty z akt dwóch wychowanek.

Pomimo dtugotrwałych przeżyć traumatycznych nieletnia nadal pozostawała w patologicznym środowisku rodzinnym. Instytucje takie jak: kurator, szkoła, policja, czy społeczność lokalna nie okazały jej należytego zainteresowania, wsparcia i interwencji. Opiniowana od początku edukacji szkolnej miała problemy z przyswojeniem wiedzy szkolnej. Uczyła się stabo. Pod naciskiem ojca od 8. roku życia paliła papierosy, spożywała alkohol, wspólnie z nim uczestniczyła w libacjach. Sytuacja rodzinna wptywała negatywnie na stosunek do obowiązków szkolnych i wyniki edukacyjne. Nieletnia miała poczucie wyalienowania w grupie rówieśniczej, czuła się gorsza od koleżanek i kolegów. Wstydziła się siniaków spowodowanych agresja ojca, była zmęczona, niewyspana, zaniedbana higienicznie, niedożywiona, często pod wptywem alkoholu. Niepowodzenia dydaktyczne zniechęcaty ja do nauki, zaległości nawarstwiały się. Zaczęła wagarować, przebywała z osobami starszymi przejawiającymi zachowania aspołeczne, tamała regulamin szkoły, lekceważyła obowiazki, paliła papierosy na terenie szkoty, przejawiała agresje werbalna wobec rówieśników i nauczycieli. Pomimo absencji nie powtarzała żadnej 
klasy. Problemy wychowawcze nasility się w gimnazjum. Nadal kontaktowała sie ze środowiskiem zdemoralizowanym, upijała alkoholem, eksperymentowała $z$ narkotykami, przejawiała agresje fizyczna wobec otoczenia, dokonywała kradzieży. (...) Kilkakrotnie była przewożona na izbę wytrzeźwień. W sytuacjach, gdy rzeczywistość ja przerastała, wyładowywała agresje na sobie i dokonywała samookaleczeń. W(...) sąd postanowił umieścić ja w MOW. Środek ten nie został wdrożony. (...) nieletnia będąc w stanie nietrzeźzości 2,6 promila, postugując się nożem kuchennym, zadała ojcu cios w klatkę piersiowa. W związku z powyższym, na mocy postanowienia została umieszczona w SdN (Nieletnia 2Z).

Z badania psychiatrycznego wynika, że [nieletnia - przyp. M.N-B] była w domu wychowywana przez matkę i ojczyma. Atmosfere wychowawcza określa jako dobra, jednak podaje, że ostatnio, od około 6-7 lat, było gorzej. Ojczym dużo pit, w domu byty awantury, rękoczyny i interwencje policji (Nieletnia 8Z).

Od wcześnie podjętych działań zapobiegawczych zależą dalsze losy młodzieży zagrożonej demoralizacją czy też przejawiającej pewne utrwalone jej symptomy. Brak jakiejkolwiek reakcji we właściwym czasie ze strony społeczeństwa może spowodować nasilenie się pierwszych symptomów niedostosowania społecznego, zapoczątkowanego w okresie dzieciństwa czy wczesnej młodości. Ponadto, istnieje duże niebezpieczeństwo, że nieletni ci kiedy dorosną, nie będą w pełni przystosowani do życia w społeczeństwie, co przyczyni się do zasilenia przez nich przestępczości dorosłych.

Tabela 7

Liczba reakcji podjętych wobec badanych $(\mathrm{N}=60 ; 100 \%)$

\begin{tabular}{|l|c|c|c|}
\hline \multirow{2}{*}{$\begin{array}{c}\text { Liczba podjętych } \\
\text { reakcji - przedziały }\end{array}$} & \multicolumn{2}{|c|}{ Płeć badanych } & \multirow{2}{*}{ Liczba nieletnich } \\
\cline { 2 - 3 } & dziewczęta $(\mathrm{n}=34)$ & chłopcy $(\mathrm{n}=26)$ & 9 \\
\hline Do 5 & 5 & 4 & 29 \\
\hline $6-10$ & 15 & 14 & 11 \\
\hline $11-15$ & 7 & 4 & 8 \\
\hline $16-20$ & 5 & 3 & 3 \\
\hline Powyżej 21 & 2 & 1 & 60 \\
\hline Razem & 34 & 26 & \\
\hline
\end{tabular}

Źródło: badania własne.

Grupując powyższe dane (liczba podjętych reakcji) w przedziały, to jest: do 5, od 6 do 10, od 11 do 15, od 16 do 20 i powyżej 20, można stwierdzić, że najliczniejszą grupę - prawie połowa badanych wychowanków z ZP i SdN (29 osób) - stanowili nieletni, wobec których podjęto od 6 do 10 reakcji. Wo- 
bec prawie co 5 . badanego wychowanka podjęto od 11 do 15 reakcji, a wobec co 10 . wychowanka od 16 do 20 . W 3. przypadkach doliczono się ponad 21 reakcji. Z obliczeń średniej arytmetycznej dla podjętych reakcji wynika, że średnio wobec jednego badanego wychowanka zakładu poprawczego i schroniska dla nieletnich podjęto ponad 10 reakcji - 10,52. Taki stan rzeczy (uzyskane wyniki badań) potwierdza dyrektor ZP i SdN (fragment jego wywiadu):

Bardzo często jest tak, że chłopiec trafia do nas i jest już tak bardzo zaniedbany, jeśli chodzi o działania pedagogiczne, że ciężko cokolwiek z nim zrobić. (...) gdyby były w Polsce skuteczne formy pomocy rodzinie, szkole, to chłopcy, którzy tej pomocy potrzebuja, pewnie by przestępczości unikali. Sa w Polsce rozmaite instytucje, które pomagaja takim rodzinom, ale z doświadczenia dobrze wiem, że to bardzo często jest fikcja, że chodzi o to, żeby gdzieś tam sobie odfajkować, że zajmujemy się rodzina, a tak naprawdę ta rodzina jest pozostawiona sama sobie i nikt jej nie pomaga ${ }^{10}$.

\section{Wnioski z badań}

Z analizy danych wynika, że umieszczenie w placówce resocjalizacyjnej (zakład poprawczy, schronisko dla nieletnich) poprzedzone jest niejednokrotnie zastosowaniem wielu środków wychowawczych przez sąd rodzinny, począwszy od ustanowienia nadzoru kuratora nad nieletnim (które łącznie odnotowano aż w 30 przypadkach), przez umieszczenie w placówce opiekuńczo-wychowawczej typu socjalizacyjnego i interwencyjnego (15 razy), aż po umieszczenie w młodzieżowym ośrodku wychowawczym (6 przypadków). W dokumentacji odnotowano wystąpienie jeszcze jednej reakcji społecznej, w postaci orzeczenia środka wychowawczego, a mianowicie udzielenie upomnienia przez sąd rodzinny (w prezentowanych analizach pojawiło się ono tylko 2 razy). Tendencja ta jest zgodna z opiniami resocjalizatorów-praktyków (kadry pedagogicznej ZP i SdN), którzy stwierdzają między innymi, że: „Ogniwo ośrodka poprawczego (zakładu poprawczego) jest ostatnim ogniwem w oddziaływaniach wychowawczych, jakie ma do dyspozycji sąd rodzinny"11. Nakreślona sytuacja (prezentowane wyniki badań), dotycząca podejmowania działań mających na celu zapobiegać i ograniczać zjawisko demoralizacji i przestępczości, wpisuje się w pogląd innego praktyka (dy-

${ }_{10}$ M. Noszczyk-Bernasiewicz, Nieletni przestępcy w percepcji personelu i nadzoru resocjalizacyjnego oraz studentów resocjalizacji, Katowice 2010, s. 190.

11 Fragment wywiadu przeprowadzonego przez Monikę Noszczyk-Bernasiewicz z jednym z dyrektorów ZP i SdN w grudniu 2010 roku. Zob. więcej w: M. Noszczyk-Bernasiewicz, Nieletni przestępcy, s. 190. 
rektora ZP i SdN), który zwraca w swojej wypowiedzi uwagę na inny jeszcze aspekt zjawiska:

nie sposób skutecznie pracować z chłopcem, który już dokonał czynu karalnego, bowiem gdzieś przegapiliśmy ten moment, kiedy on potrzebował pomocy, za późno została wyciagnięta do niego ręka $i$ w zasadzie to co my robimy, to jest próba pomocy, ale bardzo często już nieskuteczna, bo spóźniona ${ }^{12}$.

Odnosząc się do tej opinii, jak i do zebranych danych można stwierdzić, że większego wsparcia wymaga sposób sprawowania opieki rodzicielskiej nad badanymi, a zwłaszcza czas i sposób podejmowania reakcji przez instytucje państwowe - działań zaradczych - w tym przez sąd rodzinny. Analiza czasu pomiędzy wystąpieniem pierwszych symptomów demoralizacji a podjętą reakcją ujawniła, że jedynie w 9. przypadkach (na 60) instytucjonalny aparat państwowy podjął reakcję w okresie pierwszego roku od zaistnienia początkowych objawów niedostosowania. W 6. przypadkach liczba reakcji, jaką zastosowano w przebiegu życia badanych nieletnich wyniosła 20 i więcej, co pokazało z jednej strony istnienie systemu, który zdolny jest do uruchamiania wielu różnorodnych reakcji wobec symptomów demoralizacji i przestępczości nieletnich, ale z drugiej obnażyło małą skuteczność tych reakcji. Każda kolejna reakcja nie potrafiła bowiem odwrócić nieuchronnego procesu nasilania się zachowań antyspołecznych u nieletnich, które doprowadziło ich ostatecznie do umieszczenia w ZP i/lub SdN.

Zofia Ostrihanska i Dobrochna Wójcik ${ }^{13}$ uważają, że u większości nieletnich sprawców popełnienie czynu karalnego nie jest czymś przypadkowym. Przejawiają oni już dużo wcześniej objawy demoralizacji, a wielu z nich miało poprzednio sprawy w sądzie rodzinnym. Patrząc zatem na tę kwestię z punktu widzenia funkcjonowania całego systemu profilaktyki przestępczości nieletnich, można powiedzieć, że są to osoby, wobec których system zawiódł: nie podjęto działań lub podjęte okazały się nieskuteczne. Uzyskane wyniki badań jednoznacznie pokazują, że wkroczenie nieletniego na droge przestępczą w większości przypadków nie ma charakteru przypadkowego, ale jest wynikiem działania wielu przyczyn. Poprzedzone jest ono niejednokrotnie wcześniejszymi sygnałami ostrzegawczymi, wynikającymi z zaburzonego rozwoju dziecka. Dlatego, istotnym postulatem jest konieczność wczesnego i właściwego reagowania ze strony rodziców, opiekunów, nauczycieli, psychologów, pedagogów, sąsiadów, osób przypadkowych w chwili dostrzeżenia pierwszych niepokojących symptomów niewłaściwego zachowania czy nieprzystosowania, jakimi są: ucieczki z pojedynczych lekcji, konflikty

12 Tamże, s. 166-167.

13 Z. Ostrihanska, D. Wójcik, Zasady odpowiedzialności nieletnich wobec kodyfikacji karnej, Państwo i Prawo, 1998, 9-10, s. 205. 
z rówieśnikami, agresja w stosunku do nauczycieli, picie alkoholu, używanie dopalaczy czy narkotyków, wczesna inicjacja seksualna, czy dokonywanie ucieczek z domu rodzinnego.

\section{BIBLIOGRAFIA}

Gromkowska-Melosik A., Elitarne szkolnictwo średnie. Między reprodukcją społeczno-kulturowa a ruchliwościa konkurencyjna, Wydawnictwo Naukowe UAM, Poznań 2015.

Harasimiak G., Problem zachowań przestępczych dzieci i młodzieży, Opieka - Wychowanie Terapia, 2005, 3-4.

Kalinowski M., Z praktyki i teorii pracy profilaktycznej w środowisku wychowawczym, Wydawnictwo Wyższej Szkoły Pedagogiki Specjalnej, Warszawa 1986.

Kubinowski D., Jakościowe badania pedagogiczne. Filozofia-metodyka-ewaluacja, Wydawnictwo UMCS, Lublin 2010.

Noszczyk-Bernasiewicz M., Nieletni przestępcy w percepcji personelu i nadzoru resocjalizacyjnego oraz studentów resocjalizacji, Wydawnictwo Uniwersytetu Śląskiego, Katowice 2010.

Noszczyk-Bernasiewicz M., Ptynna struktura rodziny pochodzenia w biografiach nieletnich przestępców, [w:] Sociální pedagogika v kontextu životních etap člověka, red. M. Bargel, E. Janigová, E. Jarosz, M. Jůzl, Institut Mezioborovẏch Studií, Brno 2013.

Noszczyk-Bernasiewicz M., Demoralizacja i czyny karalne wśród nieletnich - dynamika i rozmiary, Resocjalizacja Polska, 2016, 11.

Nowak A., Młodzież o przyczynach, przejawach, skutkach i profilaktyce przestępczości nieletnich, [w:] Bezpieczeństwo dzieci i młodzieży i jego zagrożenia, red. K. Czarnecki, W. Kojs, M. Rozmus, Wydawnictwo Górnośląskiej Wyższej Szkoły Pedagogicznej, Mysłowice 2001.

Ostaszewski K., Skuteczność profilaktyki używania substancji psychoaktywnych, Wydawnictwo Naukowe Scholar, Warszawa 2003.

Ostrihanska Z., Wójcik D., Zasady odpowiedzialności nieletnich wobec kodyfikacji karnej, Państwo i Prawo, 1998, 9-10. 